\title{
Assessing the Challenge of Settlement in Budalangi and Yala Swamp Area in Western Kenya Using Landsat Satellite Imagery
}

\author{
Simon M. Onywere ${ }^{1 *}$, Zachary M. Getenga ${ }^{2}$, Shadrack S. Mwakalila ${ }^{3}$, Charles K. Twesigye ${ }^{4}$, \\ and Josephine K. Nakiranda ${ }^{5}$
}

\author{
${ }^{1}$ Kenyatta University, Department of Environmental Planning and Management, P.O. Box 4384400100 Nairobi, Kenya \\ ${ }^{2}$ Masinde Muliro University of Science and Technology, Department of Chemistry, P.O. Box 190 Kakamega, Kenya \\ ${ }^{3}$ University of Dar Es Salaam, Department of Geography, P.O. Box 35049 Dar es Salaam \\ ${ }^{4}$ Kyambogo University, Department of Biological Sciences, P.O. Box 1 Kyambogo Kampala \\ ${ }^{5}$ Makerere University, Department of Social Sciences and Arts Education, Makerere University, P.O. Box 7062 \\ Kampala
}

\begin{abstract}
The Budalangi area of Kenya exhibits high levels of rural poverty despite its natural resources potential and favourable climate. The area was mapped using multi-temporal remote sensing image data from 1973 to 2009 and participatory data collection. Floods are a recurrent environmental hazard and impede access to environmental resources and agricultural production. The physical setting of Budalangi at the floodplain of Nzoia River and increased runoff from degraded catchments are contributory factors to the flooding. Floods lead to disruption of human settlements and destruction of crops, shelter, dykes and infrastructural facilities. Disease outbreaks also increase due to destruction of sanitation facilities and relocation of settlements in makeshift camps. This implies that the policy measures that have been instituted by the government to mitigate the problem have had dismal impact in the Budalangi and Yala Swamp area. The degradation of the catchment is reflected in its sediment loading and deposition into Lake Victoria which has seen the morphology of the coastline at the mouth of Nzoia River and the aerial coverage by water in the lake change over the years. The overall loss in the area under Yala Swamp is $54 \mathrm{Km}^{2}$ from $186 \mathrm{Km}^{2}$ in 1973 to $132 \mathrm{Km}^{2}$ in 2009. The encroachment has significant implication on the wellbeing of the Yala Swamp and the Nzoia Floodplain ecosystem. The study therefore underscores the need to evolve an integrated watershed management plan for effective management of Budalangi and Yala Swamp area and the region in general.
\end{abstract}

Keywords: Rural poverty, multi-temporal remote sensing, degraded catchment, floods.

\section{INTRODUCTION}

Since Kenya's independence in 1963, the government's strategies and priorities on socio-economic development have recognised that rural development is essential for reduction of inequalities and vulnerability to famine, waterstress and land degradation. After four decades of trying, food insecurity has persisted with for example 3.7 million people affected in 1973 and 15 million people at present [1]. The 1997 welfare and monitoring survey indicated that $53 \%$ of people in rural areas of Kenya were categorized as overall poor and $51 \%$ as food poor [1]. The poor are clustered into socio-economic categories that include small-scale farmers, pastoralists, agricultural labourers, unskilled and semiskilled workers, female-headed rural households, physically handicapped, and HIV/AIDS orphans [1]. Most people in these clusters are landless and lack formal education. Recent

\footnotetext{
*Address correspondence to this author at the Kenyatta University, P.O. Box 4384400100 Nairobi, Kenya Tel: 254-20-8711575; Fax: 254-20-8710901; E-mail: onyweres@yahoo.com
}

statistics from the Kenya National Bureau of Statistics (KNBS) show that income and social services are skewed in favour of the rich $[2,3]$. The inequalities are manifested in many forms with the country's $10 \%$ of the population controlling $42 \%$ of the total wealth while the bottom $10 \%$ have access to less than $1 \%$ of the country's wealth $[4,5]$. These general inequalities in the country are reflected in Budalangi Division of Busia District in Western Kenya, the focus of this study.

Busia District extends from latitude $0^{\circ}$ to $0^{\circ} 45^{\prime \prime}$ North and longitude $33^{\circ} 55^{\prime}$ to $34^{\circ} 25$ East $\left(869.3 \mathrm{~km}^{2}\right)$ and has $137 \mathrm{~km}^{2}$ of its land under wetland conditions [6,7]. The wetlands are at Budalangi floodplain and Yala Swamp area of Lake Victoria Drainage Basin (LVDB). The Kenya Population and Housing Census report of 2009 puts Busia's population at 394,575 with a population density of 451 persons per square kilometre [8]. The population of Budalangi Division within the District is 66,723 occupying an area of $188.3 \mathrm{~km}^{2}$ putting the density of its population at 354 persons per square kilometre. Most of District falls in agro-climatic Zone II and III [9] and is well-watered humid and semi-humid with annual 
rainfall average of $1100 \mathrm{~mm}-2700 \mathrm{~mm}$ that should support rain-fed agriculture. The food crop productivity is however low and the district faces food scarcity and environmental impacts associated with general land degradation and flood impacts.

This study examined the impacts of land use activities in Budalangi and Yala Swamp Area in Western Kenya. It assesses the land cover/use trend in the study area using Landsat image data and documents the status of encroachment into the wetland areas and therefore the level of their degradation. Using a participatory process, the interpreted Landsat land cover/use classes were assessed in the field to document how the existing sector policies, institutional and legislative frameworks have contributed to the current status.

\section{MATERIALS AND METHODS}

Remote sensing image data sets were applied in assessing the land cover in Budalangi floodplain and Yala Swamp area in order to understand the socio-economic development and changes in the natural environment as previously described by [10]. Subsets of a series of Landsat images from six dates were used to study temporal changes in the area, namely:

$$
\begin{array}{lc}
\text { p183r060_1MSS19730202 } & \text { p170r060_7EMT20010205 } \\
\text { p170r060_5TM19860204 } & \text { p170r060_7ETM20030518 } \\
\text { p170r060_5TM19950402 } & \text { p170r060_5TM20090627 }
\end{array}
$$

All the data sets were standard products available from the United States Geological Survey through the Regional Centre for Mapping of Resources for Development, Nairobi. The dates for the data were chosen based on available cloudfree imagery and to analyze land cover changes for a longer period of time. To achieve one to one time series mapping and area measurement, the images were co-registered and reprojected to UTM coordinates on WGS84 Datum, Zone 36N. Visual image interpretation was done to decipher the land cover and the morphological changes along Lake Victoria coastline within the study area. Each sub-scene of the study area was subjected to visual interpretation and the areas where significant land cover/use changes have occurred were digitized onscreen using ArcView @ software. Digital Landsat satellite imagery have been used for identification and mapping of surface features [11]. [11] documents the use of Landsat Enhanced Thematic Mapper Plus (ETM +) in mapping glacial landforms in the Nunavut Territory of Canada. Other procedures used to decipher land cover patterns and the effects of anthropogenic activities are documented by [10, 12-14].

The land cover/use was mapped based on colour hue, textural and structural values identified from the satellite imagery which were also used in delineating the land cover/use boundaries. [15] describes a method of change detection using the principal component analysis using imagery of two dates. He identifies stable land cover sites and uses a conceptual model to indentify land use change. In this study we use the false color composites of band 7 (red), band 4 (green) and band 2 (blue) for the Thematic Mapper (TM) and the Enhanced Thematic Mapper (ETM) subset scenes for visual interpretation. Edge enhancement was carried on the data to enhance the detection of boundaries and linear features. On the false color composite images, the green color hues represent vegetation, whilst the dark blue to bright blue color hues represents water bodies, depending on the level of siltation. The soils appear in shades of purple and brown and form the background of the image. The bands used for generation of the false color composites for the Landsat Multispectral Scanner (MSS) data were bands 2 (red), 4 (green) and 1 (blue). In this band combination silted water appear in purplish color hue. The land cover classification was done based on visually delineated boundaries and corresponding to detected changes on the landscape quality, land cover changes and the land use patterns. Areas with similar colour hue and texture were grouped into one class. The area under each land cover/use class were then calculated and used for comparison and documentation of the temporal changes over the years under study. Visual image interpretation was complemented with ground truth survey and socio-economic data collection from the field during the field survey.

In the field survey, a review was first made on the area's Agricultural Reports, District Poverty Reduction Strategy Papers, and District Development Plans. A field questionnaire was administered to 55 randomly selected households. Interview schedules were also conducted with government institutions, non-governmental organizations and community based organizations involved in community development projects in the area. The field survey focused on land use, settlement trends and patterns, vulnerability of the community to flood hazards and the livelihood systems.

\section{RESULTS AND DISCUSSIONS}

The result of Landsat TM data band combinations (bands 7, 4 and 2 assigned red, green and blue colours) and Landsat MSS data (bands 2, 4 and 1 assigned red, green and blue colours) is shown in the series of images in Fig. (1a) 1972, (b) 1986, (c) 1995 and (d) 2009. The equivalent land cover/use classes digitized onscreen from visual interpretation of the images are also shown in Fig. (1) alongside the images. The computed areas of the land cover/use are presented in Table 1. Nzoia River itself has a remarkably and consistent south-westerly flow as seen in Fig. (1). The flow is over the Mumias Granite indicating a tilt and structural control on the river by the granite. Most of the area under study suggested the presence of open ground as seen from the generally purple to brown background colour hue throughout the image area except at the Yala Swamp. The open ground was mainly under small scale arable farming comprising of food crops such as maize, cassava and sweet potatoes [Agriculture (dense-Busia) and Agriculture (denseSiaya)]. The north-eastern part of the study area had a predominantly brown background with green hue and was mapped to contain shrub and bush land (Bushlands).

The changes in the coastline morphology of Lake Victoria within the study site are as a result of heavy siltation at the mouth of Nzoia River. The sediment fan has been building into the Lake leading to a change in the structure of the bay to the south of Port Victoria which has closed up over the period of time under study. The estuarine structure of the mouth of Nzoia River has also changed and it had by year 2009 developed a delta with 3 distributaries. The siltation 

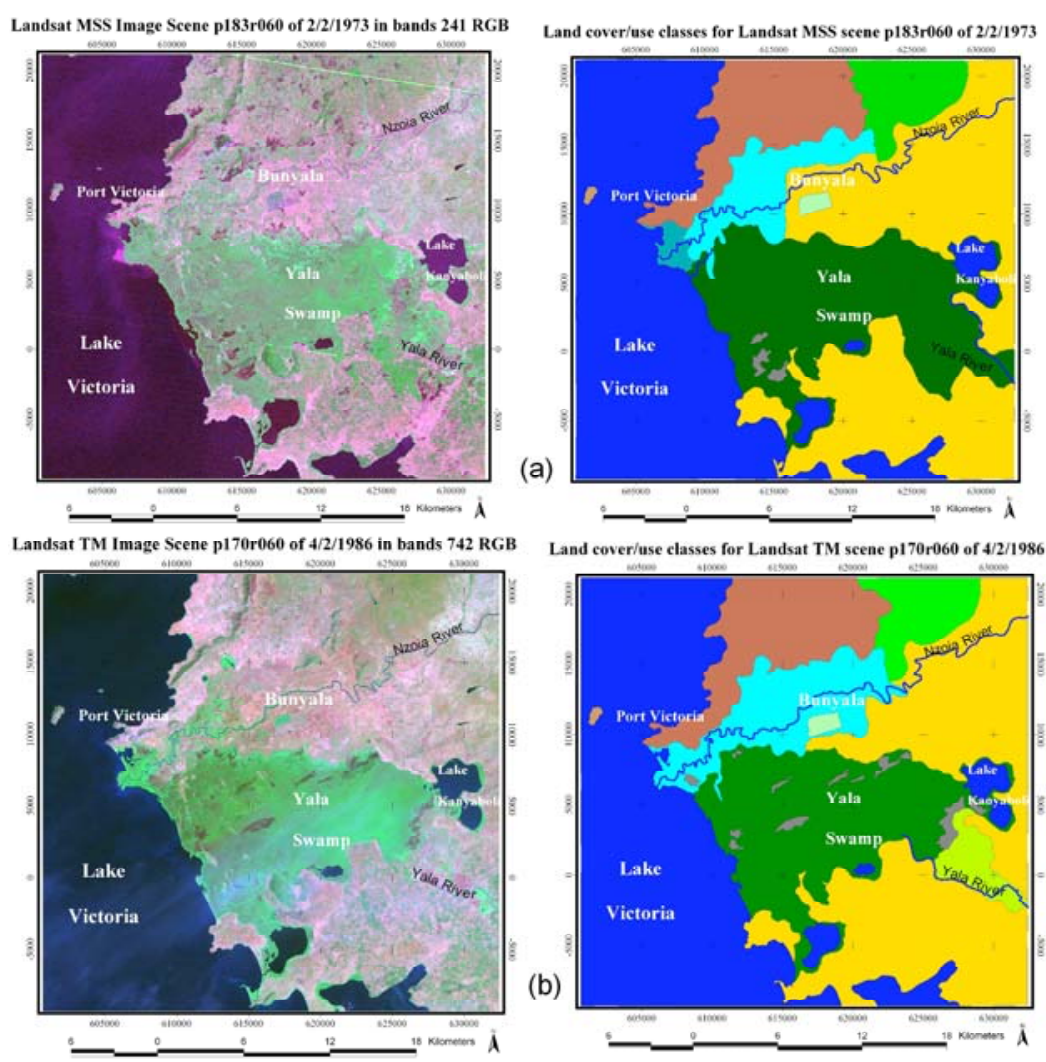

Landsat TM Image Scene p170r060 of 2/4/1995 in bands 742 RGB Land cover/use classes for Landsat TM scene p170r060 of $2 / 4 / 1995$
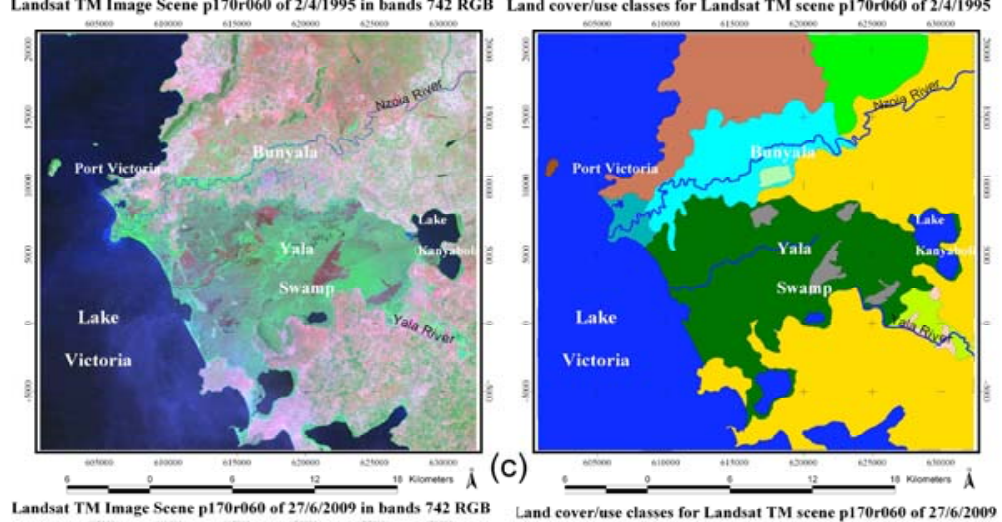

(c)
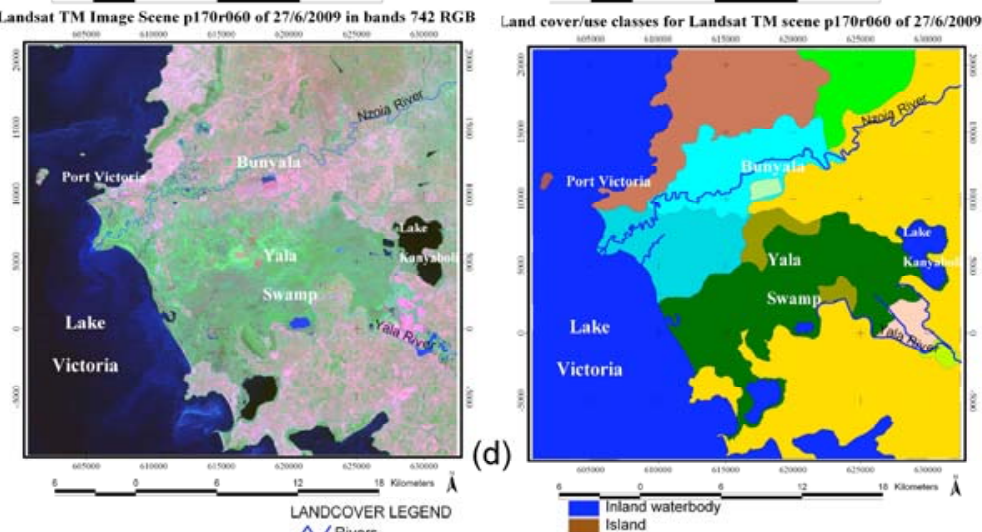

- Agriculture(dense-Busia)

ala rice irrigation

Bunyala rice
Burnt Areas

Bushlands
Floodplain-Budalan

Floodplain-Budalang

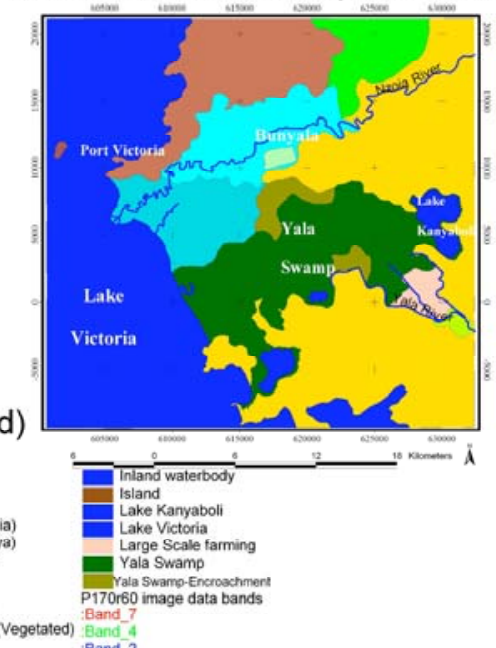

Fig. (1). False colour composites and land cover/use classes interpretation equivalents of (a) Landsat MSS of 1973, (b) Landsat TM of 1986, (c) Landsat TM of 1995 and (d) Landsat ETM+ of 2009 for the study area. 
Table 1. Land Cover / Land Use Classes Digitised from the Landsat Image Data of 1973, 1986, 1995 and 2009

\begin{tabular}{|c|c|c|c|c|}
\hline LANDCOVER & 1973 Area $\left(\mathrm{Km}^{2}\right)$ & 1986 Area $\left(\mathrm{Km}^{2}\right)$ & 1995 Area $\left(K^{2}\right)$ & 2009 Area $\left(\mathrm{Km}^{2}\right)$ \\
\hline Agriculture(dense-Busia) & 78.650 & 81.740 & 78.597 & 81.741 \\
\hline Agriculture(dense-Siaya) & 275.669 & 259.457 & 262.257 & 262.257 \\
\hline Bunyala rice irrigation & 2.846 & 2.846 & 2.846 & 2.846 \\
\hline Burnt Areas & 2.979 & 8.924 & 9.615 & - \\
\hline Bushlands & 37.173 & 34.141 & 37.007 & 34.141 \\
\hline Floodplain-Budalangi & 46.961 & 75.878 & 64.990 & 59.793 \\
\hline Floodplain-Budalangi (Vegetated & 6.844 & - & 9.077 & 50.301 \\
\hline Floodplain Yala & - & 19.701 & 10.479 & 3.617 \\
\hline Inland waterbody & 6.321 & 6.321 & 6.321 & 6.321 \\
\hline Island & 0.795 & 0.795 & 0.795 & 0.795 \\
\hline Lake Kanyaboli & 9.732 & 9.052 & 9.732 & 10.671 \\
\hline Lake Victoria & 318.961 & 318.309 & 315.709 & 313.235 \\
\hline Large scale farming & & & 3.562 & 10.424 \\
\hline Yala Swamp & 186.065 & 174.518 & 180.233 & 132.085 \\
\hline Yala Swamp-Encroachment & - & - & - & 14.744 \\
\hline Total area & 972.996 & 991.682 & 991.220 & 982.971 \\
\hline
\end{tabular}

has affected the size of the area under water within the study site with the lake reducing in surface area by $5.726 \mathrm{Km}^{2}$ from $318.961 \mathrm{Km}^{2}$ in 1973 to $313.235 \mathrm{Km}^{2}$ in 2009. The development of the sediment fan at the mouth of Nzoia River is also documented by [16-18].

The human pressure on Yala Swamp is seen from the burnt areas which appear in different locations on the images of $1973\left(2.979 \mathrm{Km}^{2}\right), 1986\left(8.924 \mathrm{Km}^{2}\right)$ and 1995 (9.606 $\mathrm{Km}^{2}$ ). As seen from the image of 2009 there is actual physical cultivation in 3 areas within the swamp [Yala SwampEncroachment and Large Scale Farming]. In 1973 there was no significant recognition of the floodplain where the Yala River enters Yala Swamp since it was under vegetation cover. A floodplain area of $19.701 \mathrm{Km}^{2}$ is seen in the image of 1986 . This area reduced to $3.617 \mathrm{Km}^{2}$ as a result of development of large scale farming which grew from $3.562 \mathrm{Km}^{2}$ in 1995 to $10.424 \mathrm{Km}^{2}$ in 2009 . The large scale farming was due to development and reclamation of the Yala Swamp by a multinational food processing company. Since 1995 significant encroachment into the swamp by small scale farmers is seen from the image of $2009\left(14.744 \mathrm{Km}^{2}\right)$ as a response to the reclamation taking place by the multinational company. The overall loss in Yala Swamp is $53.980 \mathrm{Km}^{2}$, from $186.065 \mathrm{Km}^{2}$ in 1973 to $132.085 \mathrm{Km}^{2}$ in 2009. The encroachment has significant implication on the wellbeing of the Yala Swamp and the Nzoia Floodplain ecosystem.

The government's effort in improving agriculture in the area is manifested in the development of the Bunyala Rice Irrigation Scheme [Bunyala rice irrigation] that was introduced in 1972 under the National Rice Irrigation Board. This rice irrigation scheme has not expanded and has remained $2.846 \mathrm{Km}^{2}$ as interpreted from temporal images of 1973 to 2009. Lack of up-scaling rice cultivation in the area is a contradiction to the government's policy and strategy on agricultural expansion. The other area under irrigation is part of Yala Swamp Rice Project which now is under large scale farming of various crops for the export market and does not benefit the community directly. The community has been expending their small scale subsistence agriculture mainly into the wetland areas thus degrading them. Despite the establishment of other agricultural based institutions such as the Agricultural Development Corporation (ADC), Kenya Agricultural Research Institute (KARI), National Cereals and Produce Board (NCBB), Lake Basin Development Authority (LBDA) and the development of the sugarcane industry no significant impact on improved food security is seen in the area.

From the image classification data the area identified as "Floodplain-Budalangi", "Floodplain-Budalangi (Vegetated)", "Floodplain Yala" is the areas likely to be flooded and has indeed been flooded in the past. These areas show the presence of higher vegetation cover and darker purple to darker brown colour hues of the soil background indicating the presence of higher moisture. These areas are within the riparian area of Yala and Nzoia rivers. A dense vegetation cover is mapped at the mouth of Nzoia River in a stretch of about $4 \mathrm{Km}$ and at the Yala Swamp. Despite the flood risk from settling and using the floodplain the community has continued to built and cultivate there. The challenge from such settlements has been witnessed in various flood years. 


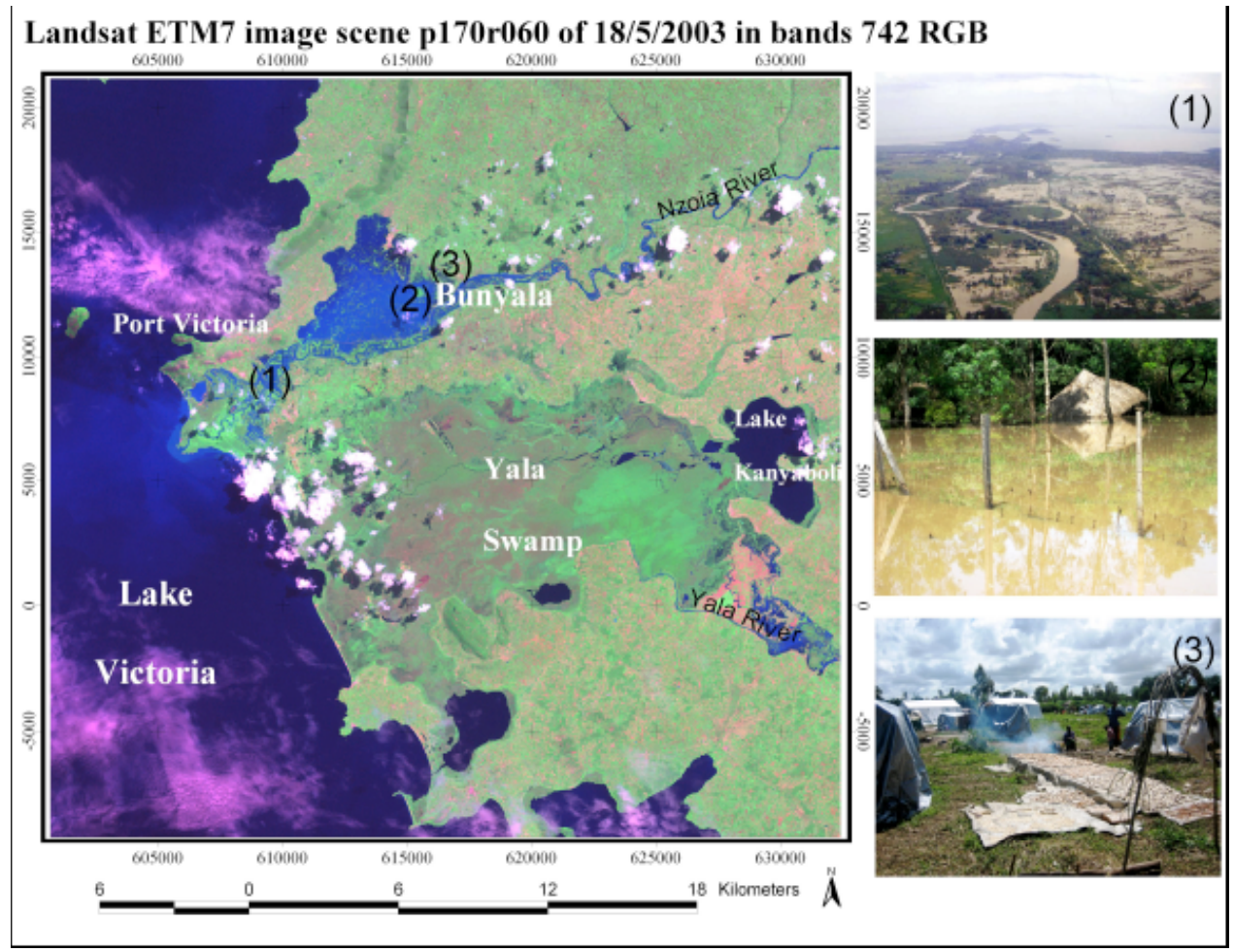

Fig. (2). The extent of the 2003 flooding and the challenges faced by the communities settled in the Budalangi floodplain. Photo 1 is courtesy of UNEP/RoK survey in May 2003; the other photos are from the field survey in July 2007 following a flood in that period.

For example, the Landsat Enhanced Thematic Mapper plus $(\mathrm{ETM}+)$ image of $18^{\text {th }}$ May 2003 and the field data collected both in 2003 and during the flood of July 2007 (Fig. 2) illustrate the nature and extent of the flood impact. The area under threat from future occurrence is seen from the interpretation and delineated as "floodplain" in Fig. (1).

The concerns on land use and settlement trends affecting the communities settled in Budalangi and Yala Swamp area indicate high levels of land degradation as manifested in the turbidity of the water and land cover change in the area [19, 20]. The general blue waters of Nzoia River seen from the false colour composites (FCC bands 7, 4 and 2; red, green and blue) images considered in this study indicate high levels of turbidity and siltation. This reflects poor land use practices at the watershed area within the catchment of Nzoia River. It is the sediment loading that has led to the change in the morphology of the coastline at the mouth of Nzoia River and subsequently affected the depth of Nzoia River. The prevalence of floods in Budalangi Division has been unique in frequency and character. The Southern half of Budalangi Division experiences floods even when there are no rains within the Division indicating a source from the upper catchment of Nzoia River which has been experiencing rapid changes in land use patterns since sugarcane cultivation was first introduced into the region in 1974. The floods and the related disasters have been recorded in 1975, 1976, 1985, and 2001 [21], in addition to those of 2003 and 2007. The long-term solution to the flood problem has been the Government's efforts to construct dykes. This has failed to contain the problem. In the 2003 example the flood waters broke the dyke and of Budalangi's population of 53,000 then, floods displaced nearly 25,000 . Some 10,000 people relo- cated to the District Officer's camp, necessitating health emergency measures to control possible outbreaks of malaria, bilharzias, cholera and other water borne diseases. As the images indicate, there has been progressive increase in the sediment load as reflected in the size of the sediment fan at the mouth of Nzoia River. If the trends continue the flood problem in the area is likely to persist pointing to the need for an integrated watershed management plan.

\section{Result of the Socio-Economic Survey}

At the national level the Poverty Reduction Strategy Programme (PRSP) and the Economic Recovery Strategy (ERS) [22] for wealth and employment creation was part of the programme aimed at reviving the economy, creating employment and reducing poverty. It was also the strategy adopted towards meeting the Millennium Development Goal's (MDGs) targets for global sustainable development and poverty reduction. The ERS gave way to the Vision 2030 from which the Government of Kenya has distilled and prepared the First Medium Term Plan (MTP). The National Development Plan (NDP) 2002-2008 [22] recognizes that $56 \%$ of the Kenyan population is afflicted by poverty and that environmental disasters such as floods can push more people below the poverty line or increase their impoverishment.

The Busia District Development Plan [7] fails to propose any programmes for flood management. This signifies major weak linkages between national planning and district planning. Despite the government's extensive grassroots based development and administrative network, which would effectively manage emergencies, and disasters such as floods, there is no attempt to mainstream disaster management into 
the National Development Plan. Consequently, sectoral budgets on disaster management are lacking. This can be interpreted as weaknesses in the economic system and class structure that allocates income and access to resources leading to impacts in terms of the people's ability to cope with flood hazards. Although humans can avoid residing in areas that experience periodical flooding, the population growth and pressure for land continue to push the people to flood prone areas. By settling in the floodplain areas, more people and households in Budalangi Division are at risk of the flood hazard.

An assessment of the socio-economic factors impeding poverty reduction in Budalangi area using a randomly sampled population of 55 indicate that the majority of the households have between 5 to 10 family members, most of whom $(72.65 \%)$ live on less than 4 acres of land. $80.9 \%$ of the families are male headed households which imply a male dominated land ownership. The basin has a rich paternalistic cultural traditions leading to cultural-based land inheritance by the male. The women, apart from those windowed, have no right to any land and although very enterprising, cannot get access to credit where land can be used as collateral. The first generation land title deeds issued shortly after independence are the only legal evidence of land ownership. The land ownership rights have slowed down the agrarian efforts of poverty reduction since the younger and more educated members $(79.3 \%$ of the Budalangi population has received any formal education) of the community has no access to their own land. This has forced them to seek land in the flood prone areas. The community members with formal tertiary education, which is responsible for imparting lifelong and economic transformation skills, accounted for only $7.5 \%$ of the population. This has serious implications on poverty reduction campaigns with numerous intervention efforts by a number of governmental and non-governmental organizations over the years having failed to turn around the development fortunes of the area.

Within the Budalangi area $46.9 \%$ of the population are engaged in farming of crops such as maize, sugarcane, cassava and beans and keeping of livestock. However, the population growth in the basin far outstrips economic growth leading to deprivation of many households especially during the time of flooding impacts. Problems bedevilling the agricultural sector in the area include donor dependence, high cost of farm inputs, lack of access to production assets and inhibitive cultural practices. The commercialisation of farming activities in the basin is also hampering local development especially where progressive farmers reside outside the basin. There is also the issue of unclear land ownership in the floodplain especially the land reclaimed from the wetlands.

The lake has also had a big influence on the population in Budalangi with the predominantly able bodied men engaged in fishing activities. Fishing account for $34.4 \%$ of the livelihoods of the households. Most young women in the area are engaged in selling the fish catches leaving the aging population and the children to take care of the farms. Middlemen from outside the district exploit the fishermen by dictating the prices of the highly perishable fish. Fishing is therefore a high-risk business and is done as cultural activity rather than a serious economic activity. There are also constant incidence of conflicts in the basin caused by boundary disputes with neighbours, regional border disputes in Lake Victoria, immigrants from Uganda, land sharing within households, land scarcity, and livestock overgrazing.

Extension service, which is essential for propagating new technologies, is inadequately dispensed across the basin. $62.5 \%$ of the respondents indicated that extension services do not serve them. This is attributed to change of government policy from supply driven to demand driven extension initiated in 1988. Common avenues of disseminating the extension services information included seminars, workshops and public gatherings (barazas). Veterinary services that had largely been offered by the Government were privatised in 1998, throwing into jeopardy livestock improvements. In most cases the Government has not followed up on the limited advice given to the farmers. Lack of emphasis on the extension policy by the government has thus made its role in the basin inconsequential to farmers. In addition, the readily disposable income from fishing is fuelling the HIV/AIDS pandemic and heightening school drop-out rate as children are pulled out of school to engage in economic production. This implies that child labour is practiced in the basin making the eradication of poverty in the long term a mirage as the poverty cycle is perpetuated.

Currently within the $982.971 \mathrm{Km}^{2}$ area under study $372.012 \mathrm{Km}^{2}$ is under subsistence crop production (see Table 1). However, large tracts of the rest of the land is composed of bushes and fallow or grazing land. The basin has the potential of growing a wide variety of crops and livestock production due to the good soils coupled with gently sloping terrain. However the high water table in the floodplain and especially during the wet season renders the area inhabitable. The floodplain is only suitable for arable farming during the dry periods. The floods destroy the accumulated assets. The government efforts to built dykes has not been effective due to high sediment load which often blocks the meandering river consequently leading to change of the course of the river. Poor farming methods are sources of the eroded soils seen in the high turbidity of the Nzoia River.

\section{CONCLUSION}

Remote Sensing data was used to depict land cover changes and their impact on the area under study. The land degradation problem in Budalangi and Yala Swamp area is compounded by rapid population growth, increased poverty levels and limited institutional capacity to deal with land use challenges. The search for more agricultural land continues to spur encroachment into Nzoia River wetlands [23]. With the growing population, the need for up-to-date and timely information on the Lake Victoria watershed is crucial for its planning and sustainable development and the current image interpretation have shown the potential to monitor the changes taking place in the area. As argued by [24], the hydrological response of a basin is governed by the basin morphology. An integrated approach to flood management should therefore involve the geomorphological understanding of the basin. [25] gives a more comprehensive approach for developing an erosion intensity map and therefore flood prone areas involving slope, lithology drainage density, 
lineament density, vegetation and land cover. Since flooding in Budalangi has been noted even when there are no rains in the area it raises concerns about the need to manage the entire Nzoia River Drainage Basin.

The siltation of lake Victoria is of major concern to the riparian communities and the East African Countries in general. This is majorly for two reasons; first, rich fertile soil is eroded and lost from the catchment areas making the catchment community more vulnerable to poverty from low crop yield. Secondly, a lot of sedimentation leads to loss of reservoir capacity, as well as degradation of water quality. Although sedimentation occurs naturally, it is aggravated by poor land use and land management practices used in the upland areas of the watersheds. The increased population is placing pressure on the land and it is the factor driving encroachment into the wetland and the floodplain areas thus exposing the community to flood risk.

Analysis of remote sensing data, for the area over the years has shown a reduction in the area covered by the swamp, paving way for settlements and agricultural land. Because of removal of vegetation cover the Nzoia swamps at the mouth of the river have lost filtration capacity for sediments, leading to incremental growth of the delta as the River discharges into Lake Victoria. The amount of sediments deposited directly into the lake is epitomized on the Landsat images by light blue colour hues of the lake water. The presence of sediments in the waters is a reflection of poor farming practices and therefore the failure of government policies, strategies and priorities on socio-economic development and poverty eradication. The policies have had dismal impacts in the Budalangi area of Nzoia River Basin. Although the various challenges have led to formation of institutions and research programmes such as the Lake Victoria Environmental Management Programme, the Lake Victoria Research Initiatives and the Nile Basin Initiative, the home grown institutions have not yielded much fruit in conservation and sustainable development for rural poverty reduction in Lake Victoria basin. An integrated sustainable flood management action plan for Budalangi Division that takes into account land reform, policy review, formulation and implementation would be required to enhance socioeconomic activities and may contribute significantly towards disaster reduction and poverty alleviation.

\section{ACKNOWLEDGEMENTS}

This research work was supported by the Lake Victoria Research Initiative (VICRES) through the Inter-University Council of East Africa (IUCEA) under SIDA/SAREC Funding. Thanks to the countries participating in the project and to Kenyatta University, University of Dar Es Saalam, Makerere University, Kyambogo University and Masinde Muliro University College of Science and Technology.

\section{REFERENCES}

[1] Republic of Kenya (RoK), "Poverty Reduction Strategy Paper 2002-2003”, Nairobi, Government Printer, 2001.

[2] Kenya National Bureau of Statistics (KNBS), "Economic Survey of Kenya, 2000", Nairobi, Government Printer, 2000.
[3] Republic of Kenya (RoK), "Economic Recovery Strategy for Wealth and Employment Creation 2003-2007", Nairobi, Government Printer, 2002.

[4[ United Nations Development Programme (UNDP), "Addressing Social and Economic Disparities", Human Development Report, Nairobi, Kenya, 2002.

[5] Society for International Development (SID), "Pulling Apart, facts and figures on Inequality in Kenya", SID, Nairobi, 2004.

[6] Republic of Kenya (RoK), "Busia District Development Plan 1997 2001", Nairobi, Government Printer, 1996.

[7] Republic of Kenya (RoK), "Busia District Development Plan 20022008", Nairobi, Government Printer, 2001.

[8] Kenya National Bureau of Statistics (KNBS), "The Kenya Population and Housing Census Report, 2009", Nairobi, Government Printer, 2010.

[9] W.G. Sombrock, H. M. H. Braun and B. J. A. Van Der Pouv, Ed., Exploratory soil map and Agro-Climatic zone map for Kenya. Hague: Cartoprint BV, 1982.

[10] D. L. Skole, W. H. Chementowski, W. A. Salas and A. D. Nobre, "Physical and human dimensions of tropical deforestation in Brazilian Amazon", Bioscience, vol. 44, pp. 314-322, 1994.

[11] C. R. Stokes and C. D. Clark, "Giant glacial grooves detected on Landsat ETM + Imagery", Int. J. Remote Sensing, vol. 24, no 5, pp. 905-910, March 2003.

[12] R. K. Jaiswal, S Mukherjee, J. Krishnamurthy and R. Saxena, "Role of Remote sensing and GIS Techniques for generation of groundwater prospect zones towards rural development - an approach", Int. J. Remote Sensing, vol. 24, no 5, pp. 993-1008, March 2003.

[13] J. A. Griffith, S. V. Stehman, T. L. Sohl, T. R. Loveland, "Detecting trends in landscape pattern metrics over a 20 -year period using a sampling-based monitoring programme", Int. J. Remote Sensing, vol. 24, no. 1, pp. 175-181, Jan. 2003.

[14] R. S. Dwivedi and K. Sreenivas, "The vegetation and waterlogging dynamics as derived from spaceborne multispectral and multitemporal data", Int. J. Remote Sensing, vol. 23, no. 14, pp. 2729-2740, July 2002.

[15] K. C. Seto, C. E. Woodcock, C. Song, X. Huang, J. Lu and R. K. Kaufmann, "Monitoring land-use change in the Pearl River Delta using Landsat TM", Int. J. Remote Sensing, vol. 23, no. 10, pp. 1985-2004, May 2002.

[16] National Environment Management Authority (NEMA), "State of Environment Report for Busia District", Nairobi, Government Printer, 2004.

[17] United Nations Environment Programme (UNEP) and the Republic of Kenya (RoK), "Aerial reconnaissance of the floods and the main catchments in Western Kenya; Preliminary findings", UNEP, Nairobi, Kenya, 2003.

[18] C. K. Twesigye, S. Onywere, Z. Getenga, S. Mwakalila and J. Nakiranda, "Environmental Degradation Crisis in the Lake Victoria Basin Watershed: Evidence From Satellite Imagery and Geographical Information Systems (GIS) Analysis". Proceedings of the Nile Basin Development Forum (NBDF), Addis Ababa, Ethiopia, pp. $138-155,2006$.

[19] S. M. Onywere, Z. Getenga, S. Mwakalila, C. Twesigye and J. Nakiranda, "Watershed Degradation Analysis of Nzoia River Drainage Basin from a Policy Change Perspective and Using Remote Sensing Data", Proceedings of the 11th World Lake Conference on Management of Lake Basins for their Sustainable Use: Global Experiences and African Issues. Nairobi, Kenya, pp. 451458, 2005.

[20] C. K. Twesigye, S. Onywere, Z. Getenga, S. Mwakalila, and J. Nakiranda, The Impact of Forest Policy, Land use Systems and Climate Change on Forest Cover Dynamics in the Lake Victoria Basin", Proceedings of 2006 JKUAT Scientific, Technological and Industrialization Conference, Nairobi, Kenya, pp. 581-599, 2006.

[21] Republic of Kenya (RoK), "National draft Policy on Disaster Management", Nairobi, Government Printer, 2002.

[22] Republic of Kenya (RoK), "Economic Recovery Strategy for wealth and employment creation 2003-2007", Nairobi, Government Printer, 2002.

[23] Republic of Kenya (RoK), "Draft Report on Flood Management Strategy for Lake Victoria Basin, Kenya", Nairobi, Government Printer, 2004. 
[24] V. Jain and R. Sinha, "Geomorphological manifestations of the flood hazard: Remote sensing based approach", Geocarto International, vol. 18, no. 4, pp. 51-60, Dec. 2003
[25] N. S. Vaidyanathan, G. Sharma, R. Sinha and O. Dikshit, "Mapping of erosion intensity in the Garhwal Himalaya". Int. J. Remote Sensing, vol. 23, no 20, pp. 4125-4129, Oct. 2002.

Received: December 14, 2010

Revised: April 20, 2011

Accepted: April 22, 2011

(C) Onywere et al.; Licensee Bentham Open.

This is an open access article licensed under the terms of the Creative Commons Attribution Non-Commercial License (http://creativecommons.org/licenses/by-nc/3.0/g) which permits unrestricted, non-commercial use, distribution and reproduction in any medium, provided the work is properly cited. 